\title{
ANALYZING SPEAKING PROBLEMS FACED BY EFL COLLEGES LEARNERS
}

\author{
Anita Suciati Rahayu1, Erika Ayu Anggraeni², Irfan Saputra ${ }^{3}$, Novia Umi Astari ${ }^{4}$, \\ Vegi Mahlul Betiya ${ }^{5}$, Linda Septiyana ${ }^{6}$ \\ IAIN Metro, Lampung \\ a.suciatir@gmail.com
}

\begin{abstract}
The purpose of this qualitative research is to examine what problems are faced by EFL Colleges Learners in speaking English especially at IAIN Metro, Lampung. The researcher took the fourth semester at English Department of IAIN Metro as the subject. The total numbers of the subjects were ten (10) students. The researcher interviewed the students to find out about the EFL collages learners difficulties in speaking skill. The findings showed that there are four important themes which emerged in this study, namely (1) the students are lack of Vocabularies, (2) The grammar is not well mastered by the students, (3) the students are afraid of negative responses from others, and (4) the students have low self-confidence in speaking English.
\end{abstract}

Keyword: colleges learners, speaking, speaking problems

\section{INTRODUCTION}

Nowadays, English as an international language is used in many ways, such as business communication, technology, and academics. English is a worldwide phenomenon that is very necessary to communicate with people from various language and cultural backgrounds and in various backgrounds. Both native and foreign languages every human has an ability to learn it. One of them is English. Crystal (2005) stated that as a foreign language, English is used as a tool of communication among countries particularly in political, social, educational and economic development (Ota, 2018, p. 1).

English has an important role in everyone's life. English is one that is used throughout the world. The use of English has become common in all fields such as Education, Medical, Media and Business, etc. English is widely used in companies and workplaces that demand comprehension and ability to communicate at least for multinational transactions in English. English is also an official language that is used in many countries so that is the reason why most official institutions in this globe use it and require members to understand the language. English gives people access various information via internet because it can reach and serve many people.

According to Regulation by Minister of National Education No.23, 2006 on the Graduate Competence standard for primary and secondary schools, the teaching of English includes the four language skills: listening, speaking, reading and writing (Melian \& Solihat, 2019, p. 257). Listening and reading are considered receptive skills, whereas speaking and writing are productive ones (Melian \& Solihat, 2019, p. 257). Speaking believed as one important aspect that must be mastered in supporting other aspects because speaking is used to communicate and express ideas, feelings, and thoughts to others. It cannot be denied that the role of humans as social creatures will surely meet and interact with other people, of course a strategy is needed so 
that the message that is delivered to the interlocutors can be received and understood well. Through speaking we can interact with global citizens (Septiyana, 2019, p. 155).

Bryne (1984) defines speaking as a two-way process between speaker and listener. The process involves productive and receptive skills of understanding (Setiawati et al., 2017, p. 2). The students will have good communicative competence and will get high level of achievement if they master the four skills of English (Liton, 2012) (Ota, 2018, p. 2). However, speaking English is not always a simple matter. English education practitioners should spin from conventional instructions that cannot promote skills needed in globalization era (Nasution \& Sukmawati, 2019, p. 47).

A study conducted by Khaemkaw (2008) entitled "Needs and Problems in English Listening and Speaking Skills" shows that speakers of English as a Foreign Language (EFL) face problems when trying to speak in English (Nugraha \& Putra, 2016, p. 2). In speaking skills, students are expected to be able to use English as a daily language. In using grammar, students must use good and correct grammar to improve students' speaking abilities. In using pronunciation, students are expected to pay attention to intonation and spelling, so that the listener can understand it well.

Based on the fact in real life, most of the students are confronted with problems in speaking. Most of them cannot speak English well for many factors. The only skill which uses the combinations of vocabulary, pronunciation, accent, and even grammar is speaking. Accordingly, when students can perform good speaking skill and use it continuously, they think that their speaking ability improves. But those who do not perform speaking skill persistently, their speaking skill will not improve.

Average people assume that students of English department perform English in every conversation inside or even outside the class. However, the fact shows differently that they rarely practice speaking English even in the class where the material is related with English as prefer speaking in their mother tongue when they have interaction with their friends.

As we saw in speaking class, some of the students were too shy to speak in English because they have to speak in front of the class and they felt afraid they will make a mistake and their friends will laugh at them. Sometimes the students want to speak English but they do not have idea on what to speak. Ironically, some students even face moments where they lose their planned-to-say words that actually were already set in their mind but they cannot convey it well.

Many researches were conducted by researchers around analyzing the speaking problem faced by the students. Noprival (2017) in his study entitled Students' Voice: EFL Speaking Problems On English Day Program At One Senior High School In Indonesia, found that “ ... to examine the problems of speaking English the students face on performing English day at one senior high school in Jambi, Indonesia". Nugraha \& Putra (2016) entitled Students' Speaking Problems: A Case Study of Chemistry Students at UPI Bandung revealed that “... the students face some main problems in speaking. They are pronouncing words with English sounds that do not exist in Bahasa Indonesia, diction-related issues, and speaking that fits to grammatical rules". Hadijah (2014) with her findings titled Investigating The Problems Of English Speaking Of The Students Of Islamic Boarding School Program At Stain Samarinda discovers that “... the students' reason when asked about what problems they are facing in speaking practice were (1) they have limited idea on the indicators of speaking skills such as grammar, pronunciation, fluency and comprehension, and vocabulary; (2) they have own personal reasons, such as being unconfident to practice speaking, having lack of speaking-practice frequency, having difficulties at understanding and practicing the speaking materials found in the English textbook, having limited time for preparing the speaking test, the environment (dormitory) which do not support them to acquire and practice English as a medium of daily interaction, and their preference to study the Islamic knowledge and Arabic than English. Although previous researches have addressed the English problems faced by students, there is no research has specifically focused on speaking problems in EFL Colleges Learners. The novelty in this article is about the 
researcher was interested to know what the students' problems in learning speaking English are, especially in EFL collages learners.

\section{METHOD}

In carrying out this research, this research used descriptive qualitative research conducted at English Education Department of IAIN Metro. Descriptive refers to the researcher's needs to collect the data to describe what actually happens in the field. The data that have been collected is classified based on the characteristics, kinds, or the condition. In addition to collecting the data, qualitative research refers to finding new ideas and criticisms to the process that has happened. The result can enrich and improve the students' learning process (Arikunto, 2013).

The researcher took the fourth semester at English Department of IAIN Metro as the subject. The total numbers of the subjects were ten. In finding data, the researcher conducted interview. Arikunto (2013:198) asserted that, "Interview is a dialog to acquire information from someone interviewed. Interview is used to appraise someone's condition. For example: To look for the data about variable of students ' background, parents, education, attention, perception" (Faradhibah \& Nur, 2017, p. 186). The kind of interview in this research used guided interview. The researcher needs to arrange some questions that used to ask respondent before conducting an interview. The researcher interviewed some students and the lecturer to find out about the EFL collages learners difficulties in speaking skill.

\section{FINDINGS AND DISCUSSION}

The purpose of this qualitative research is to examine the English language problems faced by EFL Colleges Learners especially at IAIN Metro, Indonesia. Analysis of interview data revealed that there were several issues concerning students' problems in speaking English, including (1) Lack of Vocabulary, (2) The grammar is not well mastered, (3) Afraid of negative responses from others, and (4) Low self-confidence in speaking English.

\section{Lack of vocabulary}

We certainly need some vocabulary as a media to transfer messages to the recipient as a communication tool. In mastering spoken English, vocabulary is the main key so we can get involved in a conversation. In this study, the participants felt that their ability to speak English was still not good. Below are some related parts of the interview transcriptions:

Student (JM)

"My difficulty in speaking is the lack of vocabulary that I have."

Student (AM)

"Lack of vocabulary makes me difficult to speak English. “

Student (NG)

"I don't have enough vocabulary to speak."

Student (ZE)

"Vocabulary is the main problem if you want to have a good ability to speak."

The data showed that vocabulary is one of the problems faced by the participants in speaking English. In fact, one participant admitted that vocabulary was the main problem. By recognizing their weaknesses in vocabulary, it makes them less confident to speak in English.

\section{The grammar is not well mastered}

The main purpose of oral communication is to convey what will be delivered whether it is a feelings or ideas. Grammar is one of the elements of language to communicate things well. In 
this study, the participants admitted that they had difficulty in speaking English because they were afraid of the grammar would be wrong. These are some statements from them:

Student (PR)

"I have to set the grammar before I spoke and it made me confused and hesitant to speak."

Student (FS)

Student (FQ)

"I am afraid of the wrong use of grammar. "

"I need to improve the grammar. The quote above shows that grammar makes participants thinking twice before speaking."

In other words, they were too focused on the correct use of grammar (accuracy) in speaking so that it makes students inactive in speaking English. Basically, in oral communication if they can understand each other about something being discussed then it can be accepted in oral communication.

\section{Afraid of negative responses from others}

Next, what we encountered was participants' fears of negative responses from other students. This is a natural fear, but it shouldn't have happened. We are not native speakers so we don't need to feel to speak like them. Having errors in vocabulary selection, pronunciation and intonation are normal. They reported:

Student (AO)

"I was laughed and it really hurt, nobody's perfect, right?"

Student (RQ)

"They said "you are not good in speaking English, the way you speak is very Javanese". "“

Student (WN)

Student (AG)

"When I did mistake in pronunciation, they judged me."

"They laughed at me and repeating my false pronunciation."

The data showed that negative responses from other people when they try to speak English are still common. The participants admitted they were better off silent because of the negative responses from their friends.

\section{Low self-confidence in speaking English.}

Basically, the courage in conveying what language has been learned is needed for foreign language learners. English learners need to practice English confidently, so they are get used to speak English. In this study, I found some participants had low self-confidence in speaking English. As stated in the following statement:

Student (LP)

"I am not confident, I am afraid of making mistakes."

Student (FS)

"I am not quite fluent in using English as a daily language. The use of vocabulary and the accent or intonations of my speaking are still not good enough. " Student (ZE)

"My grammar and pronunciation are still bad."

\section{Student (JM)}

"The person that I talked to was better, it made me feel insecure so I prefer silence."

The data showed that low self-confidence makes participants less confident in speaking English. In addition, the participants felt insecure to speak English with those who had better English skills. These reasons made the participants unwilling to speak in English. 
In learning English, there are four things that must be understood by everyone who studies it so that he can truly be said to be proficient in English. Reading, writing, listening, and speaking, these are all elements in English that you must know clearly and continuously. Speaking English is an important element in learning English. By mastering the science of speaking English, of course we can communicate with anyone considering that English is one of the global languages that will surely be used by humans around the world. Basically in learning, we always need a friend or mentor to help us to be able to justify or train to be smart. Well, to master the pronunciation in English, the presence of mentor or friend to the other person is also an important element that must be done. However, opportunities in practicing English are very limited because English is only a subject during class. To improve English skills, some lecturers have their own policies in the learning process.

We still found some problems that participants faced when they wanted to speak English. In this study, researchers found that the source of problems in speaking was faced by participants, which had been explained and interpreted from the participant's personal point of view. There are four main problems associated with students' problems in speaking English, including (1) Lack of Vocabulary, (2) Grammar is not well mastered, (3) Fear of negative responses from others, and (4) Low self-confidence in speak English. As a result, their speaking performance is not quite smooth and prefers to be quiet because they feel there is still much to be improved. In addition, they also have personal reasons, such as fear of speaking English, they are interested in learning something other than English, lack of confidence and speaking practice, to environments that do not support speaking in English.

From the debates above, it can be concluded that practice is the most important thing in speaking. Accustomed to speak English will help a lot of conversation in speaking. English or English is a compulsory way to practice speaking skills. When we speak in English, don't think about the grammar. Just try whatever you want to talk, but it might not be organized, because later the compilation is complete. Just set the truth of the wording.

Talking about vocabulary, there is one way that might help a small pocket book that is easy and easy to help wherever, in this booklet students are required to learn some vocabulary while memorizing.

\section{CONCLUSION}

This study concluded that there are four main problems related to EFL learners problems in speaking English, including (1) Lack of Vocabulary, (2) Grammar is not well mastered, (3) Fear of negative responses from others, and (4) Low self-confidence in speaking English. The ability to speak English in EFL learners must be improved by motivating students about the importance of English for communication and global interaction today. English is an international language that is definitely used by all people in the world. By mastering the language which incidentally is the most common language in the world, it is certainly our main capital to expand our relationships throughout the world.

\section{REFERENCES}

Faradhibah, R. N., \& Nur, N. A. (2017). Analyzing students' difficulties in maintaining their coherence and cohesion in writing process. Eternal (English, Teaching, Learning, and Research Journal), 3(2), 183-194. https://doi.org/10.24252/Eternal.V32.2017.A7

Melian, O. H., \& Solihat, M. R. (2019). Analyzing students' speaking activities in teaching learning process using stad method. PROJECT (Professional Journal of English Education), 2(3), 257-262. https://doi.org/10.22460/project.v2i3.p257-262 
Nasution, S. S., \& Sukmawati, N. N. (2019). Model united nations: improving the students' speaking skill. JEES (Journal of English Educators Society), 4(2), 47-52-52. https://doi.org/10.21070/jees.v4i2.2100

Nugraha, A. S., \& Putra, J. R. (2016). | Nugraha. ENGLISH JOURNAL, 17(2), 1-13.

Ota, M. K. (2018). Developing communicative learning materials for teaching english as a foreign language to students of elementary teacher study program of flores university of East Nusa Tenggara. Jurnal Pendidikan Bahasa Inggris Indonesia, 6(1). https://doi.org/10.23887/jpbi.v6i1.2707

Septiyana, L. (2019). Designing English speaking materials using task- based language teaching (TBLT) for Islamic Economics Students. IDEAS: Journal on English Language Teaching and Learning, Linguistics and Literature, 7(2). https://doi.org/10.24256/ideas.v7i2.1031

Setiawati, N., Yufrizal, H., \& Sukirlan, M. (2017). Analyzing negotiation of meaning in speaking class at second grade sman. U-JET, 6(3). http://jurnal.fkip.unila.ac.id/index.php/123/article/view/12483 